\title{
GEOLOGICAL CONTROLS IN THE DEVELOPMENT OF CAVES IN THE SOUTH-CENTRAL OZARKS OF MISSOURI, USA
}

\author{
GEOLOŠKE ZAKONITOSTI PRI RAZVOJU JAM V \\ OSREDNJEM DELU JUŽNIH OZARKOV, MISSOURI, ZDA
}

STANKA ŠEBELA ${ }^{1} \&$ RANDALL C. ORNDORFF ${ }^{2} \&$ DAVID J. WEARY ${ }^{2}$

\footnotetext{
${ }^{1}$ Karst Research Institute ZRC SAZU, Titov trg 2, SI-6230 POSTOJNA, SLOVENIA

${ }^{2}$ U.S. Geological Survey, 926 A National Center, Reston, VA, 20192, U.S.A.
} 


\section{Stanka Šebela \& Randall C. Orndorff \& David J. Weary: Geološke zakonitosti pri razvoju jam v osrednjem delu južnih Ozarkov, Missouri, ZDA}

Področje Ozarkov v Missouriju je eden največjih kraških terenov v ZDA. Prevladujočo litologijo predstavljajo kambrijski in ordovicijski dolomiti in peščenjaki. Številne, večinoma horizontalne jame in veliki kraški izviri so značilnosti krasa Ozarkov. Od oktobra 1996 do vključno maja 1999 smo obiskali 23 kraških jam, za 18 jam v osrednjem delu južnih Ozarkov smo naredili geološke karte. Za ta članek smo predstavili geologijo štirih jam. Prevladujoča geološka zakonitost, ki vpliva na oblikovanje jam je vpad plasti in preferenčna plast stromatolitnega dolomita. Edina možna povezava med geološko strukturo in smerjo jamskih rovov je smer rovov sever-jug in smer razpok sever-jug.

Ključne besede: krasoslovje, geološka struktura, Ozarki, Missouri, ZDA.

\section{Abstract}

UDC: $551.44(77)$

\section{Stanka Šebela \& Randall C. Orndorff \& David J. Weary: Geological controls in the development of caves in the south-central Ozarks of Missouri, USA}

The Ozark Plateaus Province of Missouri is one of the largest karst areas in the USA. The dominant lithology is Cambrian and Ordovician dolomite and sandstone. Numerous, mostly horizontal caves and large springs are characteristic of Ozark karst. From October 1996 through May 1999, 23 caves were visited and geologic maps were made for 18 caves in the Ozarks of south-central Missouri. For this paper, the geology of four of the caves is discussed. The prevailing geologic control on cave development is bedding plane dip and preferred strata-a stromatolitic dolomite bed. The only recognized relationship between geologic structure and cave passage trends is the correlation of a N-S trend of cave passages to a general N-S trend in joints.

Key words: karstology, geological structure, Ozarks, Missouri, USA. 


\section{INTRODUCTION}

Geologic mapping at scales of 1:24.000 and 1:100.000 is being done in a part of the Ozark Plateaus in south-central Missouri, USA, to develop an understanding of karst and karst hydrology as related to water quality and land-use issues on public lands. The study area is located in the Current River and Eleven Point River drainage basins and includes parts of the Ozark and Eleven Point National Scenic Riverways, the Mark Twain National Forest, several state forests, and some private lands (Fig. 1). This area is characterized by many large springs, losing and disappearing streams, caves, and sinkholes. The terrain consists of steep-sided rolling hills and valleys, and entrenched, meandering streams; altitudes range from 135 to $400 \mathrm{~m}$ and the average relief is 120 to $150 \mathrm{~m}$. The rocks in the study area are Upper Cambrian and Lower Ordovician dolomite, sandstone, limestone, shale, and chert, which overlie Middle Proterozoic rhyolite and granite.

Missouri $\left(178.445 \mathrm{~km}^{2}\right)$ has more than 5.100 registered caves (Unklesbay and Vineyard 1992), the longest being Crevice Cave, Perry County, with $45 \mathrm{~km}$ of mapped passages. The longest cave in the Current River and Eleven Point River watersheds is Powder Mill Creek Cave, Shannon County, with $11,5 \mathrm{~km}$ of mapped passages. Along with geologic mapping on the surface, 18 caves also have been mapped, four of which will be discussed in detail.

\section{GEOLOGIC AND HYDROGEOLOGIC SETTING}

About 750 to $900 \mathrm{~m}$ of flat-lying to gently dipping Upper Cambrian and Lower Ordovician dolomite, sandstone, limestone, shale, and chert overlie Middle Proterozoic rhyolite and granite (Fig. 2). Dolomite is the dominant lithology. Of the Upper Cambrian and Lower Ordovician rocks, only the Potosi Dolomite and younger units are exposed in the study area. Middle Proterozoic basement rocks are exposed as knobs that protrude into the Paleozoic section as high as the Gasconade Dolomite. Caves investigated for this study occur in the Eminence and Gasconade Dolomites and the Roubidoux Formation. The Eminence Dolomite is a massive to thick-bedded, medium- to coarsegrained, light-gray, locally cherty dolomite. The Gasconade Dolomite contains a basal interbedded sandstone and dolomite member overlain by medium- to thick-bedded, fine- to coarse-grained, light-gray dolomite with several cherty horizons. The Roubidoux Formation consists of interbedded fine- to coarse-grained, commonly poorly sorted sandstone, thin- to medium-bedded, fine- to mediumgrained dolomite, and chert. All three formations contain stromatolitic dolomites.

The Ozark Plateaus Province has the form of a large structural dome. In southeastern Missouri, strata overall dip gently to the southeast toward the Mississippi embayment. Locally, strata dip steeply away from Middle Proterozoic knobs and near fault zones. Faults are generally steep and most trend to the northwest and northeast (Fig. 3). Many faults in the Paleozoic rocks appear to be aligned with Precambrian structures indicating that these faults may be reactivated along them. Faults with probable strike-slip motion have been identified in the study area by stratigraphic offset and the occurrence of fault breccia (Orndorff et al. 1999). Joints in the Upper Cambrian and Lower Ordovician rocks mostly are vertical and occur in two dominant sets, $340^{\circ}-0^{\circ}$ and $70^{\circ}-85^{\circ}$. The general trends of faults do not parallel these regional joint sets.

Upper Cambrian and Lower Ordovician strata form three geohydrologic units; two aquifers separated by a confining unit (Imes 1990) (Fig. 2). The lower aquifer, the St. Francois, is 30 to 180 


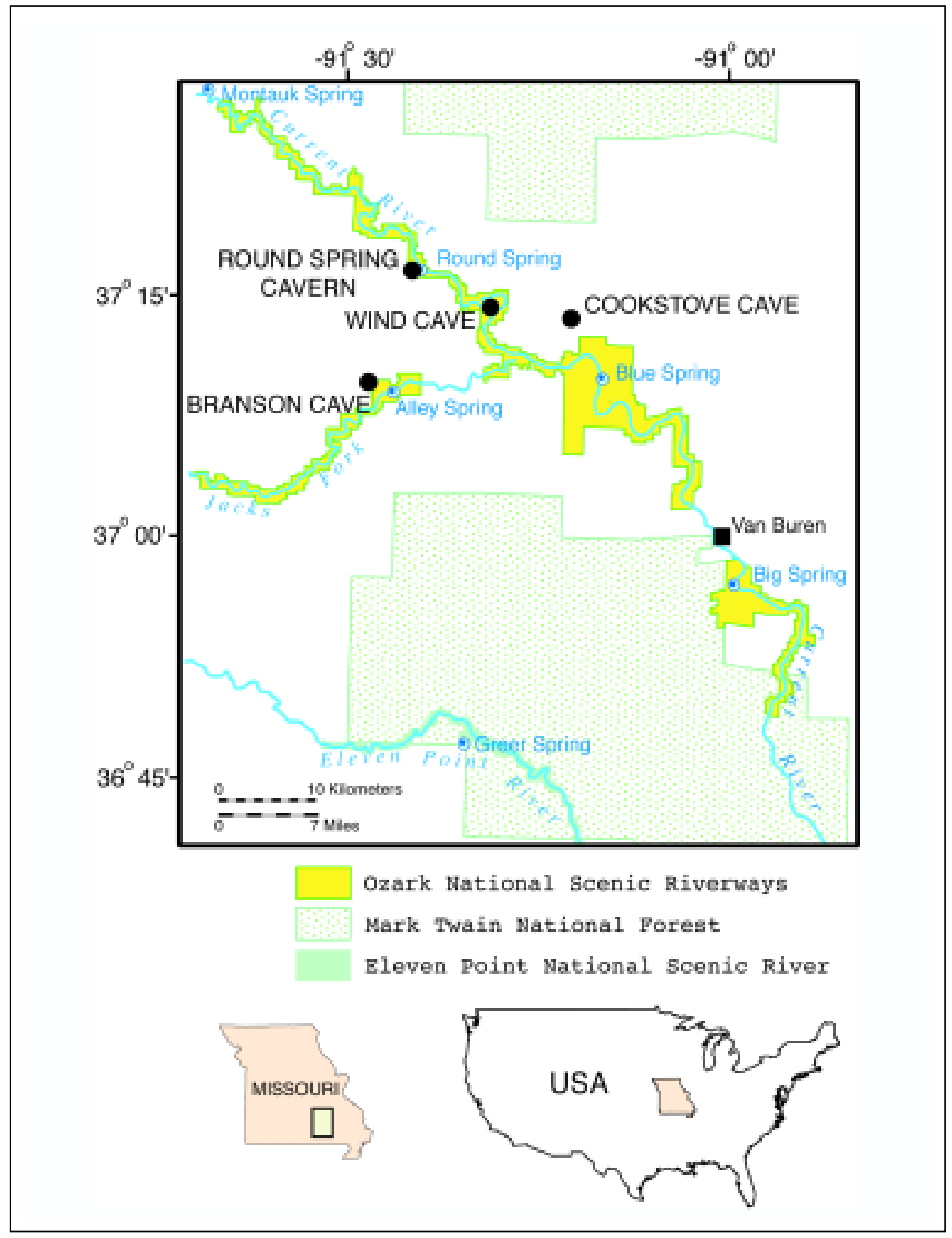

Fig. 1: Index map of study area showing public lands, large karst springs, major rivers, and locations of the four caves investigated.

Sl. 1: Karta področja raziskav z označenimi državnimi ozemlji, velikimi kraškimi izviri, glavnimi rekami in štirimi jamami, ki jih smo jih raziskovali. 
S. Šebela \& R.C. Orndorff \& D.J. Weary: Geological controls in the development of caves in the south-central Ozarks of...

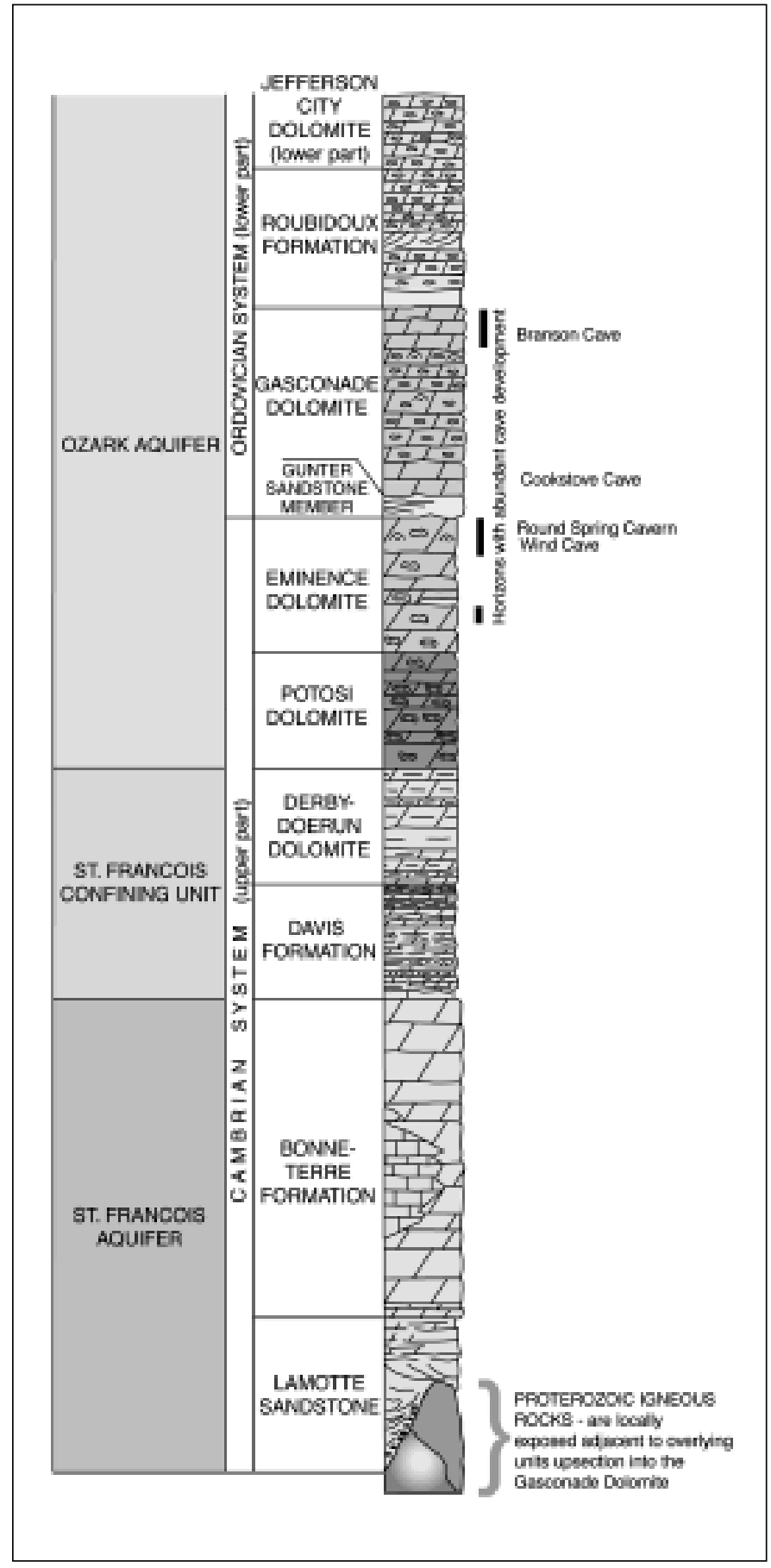

Fig. 2: Column of stratigraphic and hydrogeologic units of south-central Missouri showing stratigraphic position of caves investigated and horizons with abundant cave development.

Sl. 2: Stolpec stratigrafskih in hidrogeoloških enot $v$ osrednjem delu južnih Ozarkov z označenimi stratigrafskimi položaji raziskanih jam in horizontov ugodnih za razvoj jam. 


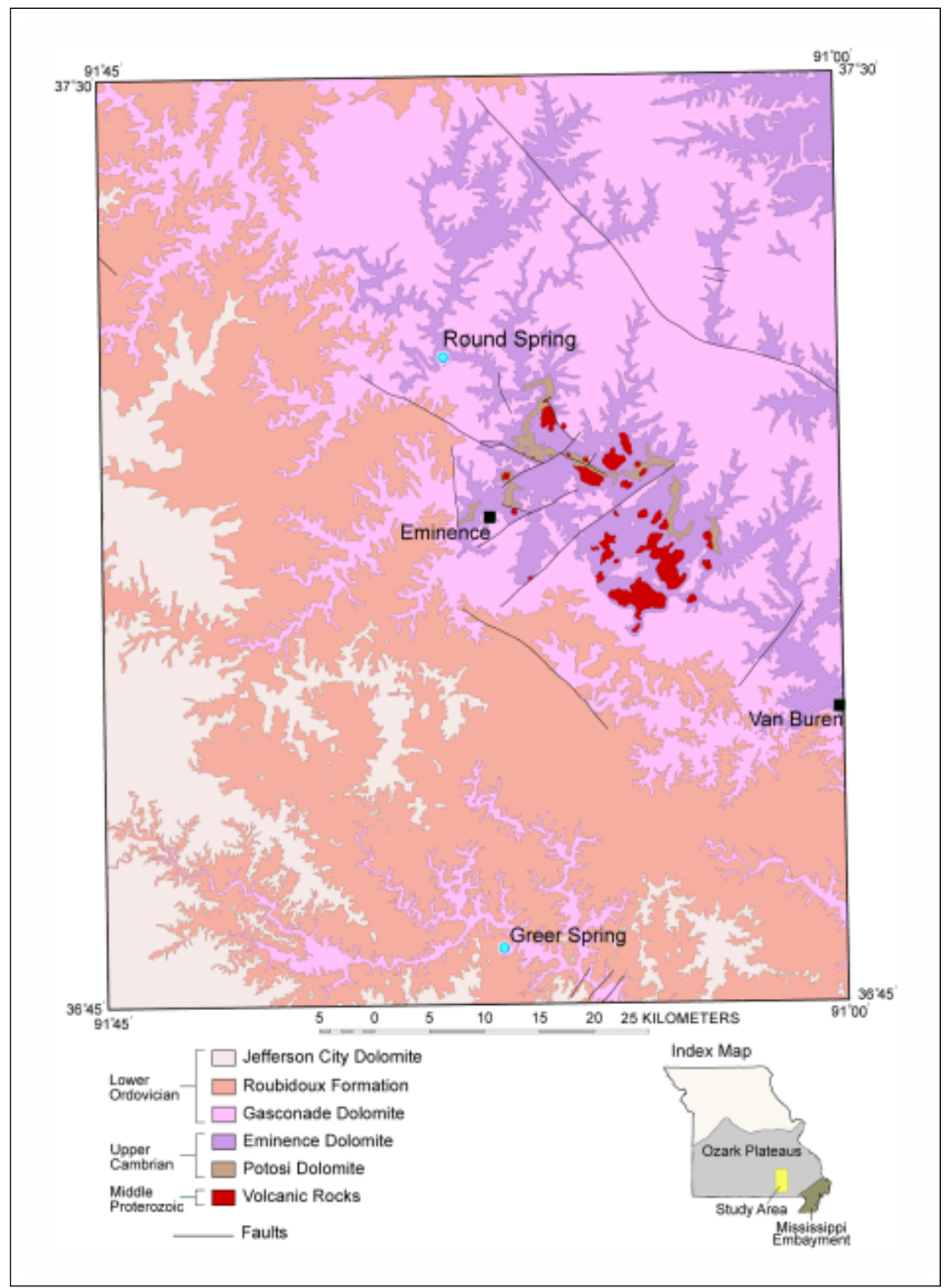

Fig. 3: Generalized geologic map of study area. Sl. 3: Generalizirana geološka karta raziskanega terena. 
m thick and consists of the Lamotte Sandstone and Bonneterre Formation. Overlying the St. Francois aquifer is the St. Francois confining unit (90-110 m thick) formed by shale, dolomite, and limestone of the Davis Formation and Derby-Doerun Dolomite. The upper aquifer, the Ozark (as much as $300 \mathrm{~m}$ thick), consists of the Potosi, Eminence, and Gasconade Dolomites, the Roubidoux Formation, and the Jefferson City Dolomite. The Ozark aquifer is the primary source for springs and streams in this area and is commonly used for domestic water supply.

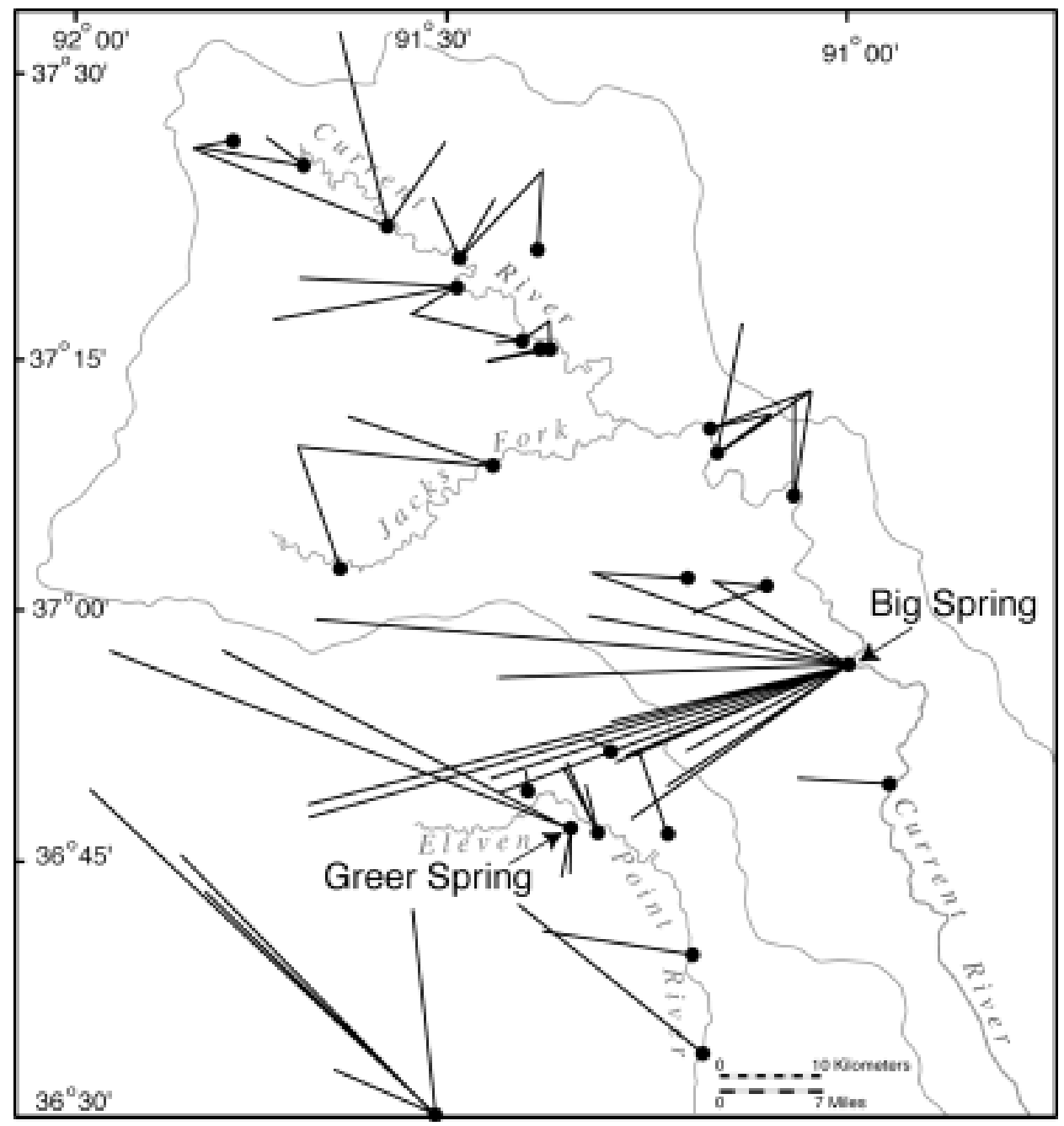

Fig. 4: Dye traces from Imes and Kleeschulte (1995) and Aley and Aley (1987). Black dots are springs where dye was detected.

Sl. 4: Sledilni poizkusi iz Imes and Kleeschulte (1995) in Aley and Aley (1987). Temne točke so izviri, kjer so določili sledilo. 
Distinctive karst features are abundant and underground drainage is significant in the study area. Some of the largest springs in the United States are found in this area, including the two largest springs in Missouri, Big Spring (average flow $12 \mathrm{~m} / \mathrm{sec}$ or 282 million gallons per day) and Greer Spring ( $8 \mathrm{~m}^{3} / \mathrm{sec}$ or 183 million gallons per day) (Fig. 1) (Vineyard and Feder 1982). All of the Ozark springs have large fluctuations in discharge related to precipitation events. The prevalence of underground drainage is indicated by many losing and disappearing streams as well as by extensive cave and conduit systems. Dye traces show that subsurface drainage crosses surface drainage divides (Aley and Aley 1987) (Fig. 4). For example, dye introduced in the Eleven Point River drainage basin surfaced at Big Spring along the Current River (Aley 1975).

\section{GEOLOGY OF CAVES}

From October 1996 through May 1999, 23 caves were visited and geologic maps were made for 18 caves in the Ozarks of south-central Missouri. For this paper, the geology of four caves is discussed. Spacing and length of joints were measured in the caves and compiled on compass-rose diagrams to determine trends. To compare joint trends with cave passage orientations, the passage trends were plotted by lenght on compass-rose diagrams.

\section{BRANSON CAVE}

Branson Cave occurs $54 \mathrm{~m}$ above an ephemeral tributary of the Jacks Fork (Fig. 1). The entrance is $6 \mathrm{~m}$ wide and $2 \mathrm{~m}$ high and is at an altitude of $268 \mathrm{~m}$. Branson Cave was described by Bretz (1956) and Brod (1990).

\section{Stratigraphy}

The cave (Fig. 5) is developed in thick-bedded, variably cherty dolomite of the upper part of the Gasconade Dolomite below the basal sandstone of the Roubidoux Formation. The entrance passage is developed in a $0,5 \mathrm{~m}$ thick stromatolitic dolomite overlain by a $0,2 \mathrm{~m}$ thick layer of laminated dolomite. The entrance passage of the cave and most of the northern passage is slightly stratigraphically lower than the northern terminus of the cave where chert is found on the ceiling. The chert layer occurs 1-1,5 $\mathrm{m}$ above the stromatolitic dolomite. The narrow eastern passage is also slightly stratigraphically higher than the entrance passage.

\section{Structure}

Bedding measurements show a gentle syncline in the entrance passage and a gentle anticline where the northern and eastern passages intersect. Both folds trend NW. Beds in the northern passage are horizontal. A fault has been shown on maps of Branson Cave (Brod 1990). Brod (1990) described the fault as being in a wall niche in the small eastern passage near its terminus. Other than the strike and sense of displacement, no other data were provided. The strike of the fault is such that it intersects the cave in only one place; however, projection of the fault trace passes close to the termini of two other passages, both of which end in breakdown. The fault may have mechanically weakened the rock or made it more conducive to solution, or both, causing structural collapse.

The most prominent joint in the eastern passage has a dip direction of $320^{\circ}-330^{\circ}$ and dips $70^{\circ}$. This is the fault of Brod (1990). This joint shows evidence of a small amount of reverse fault 


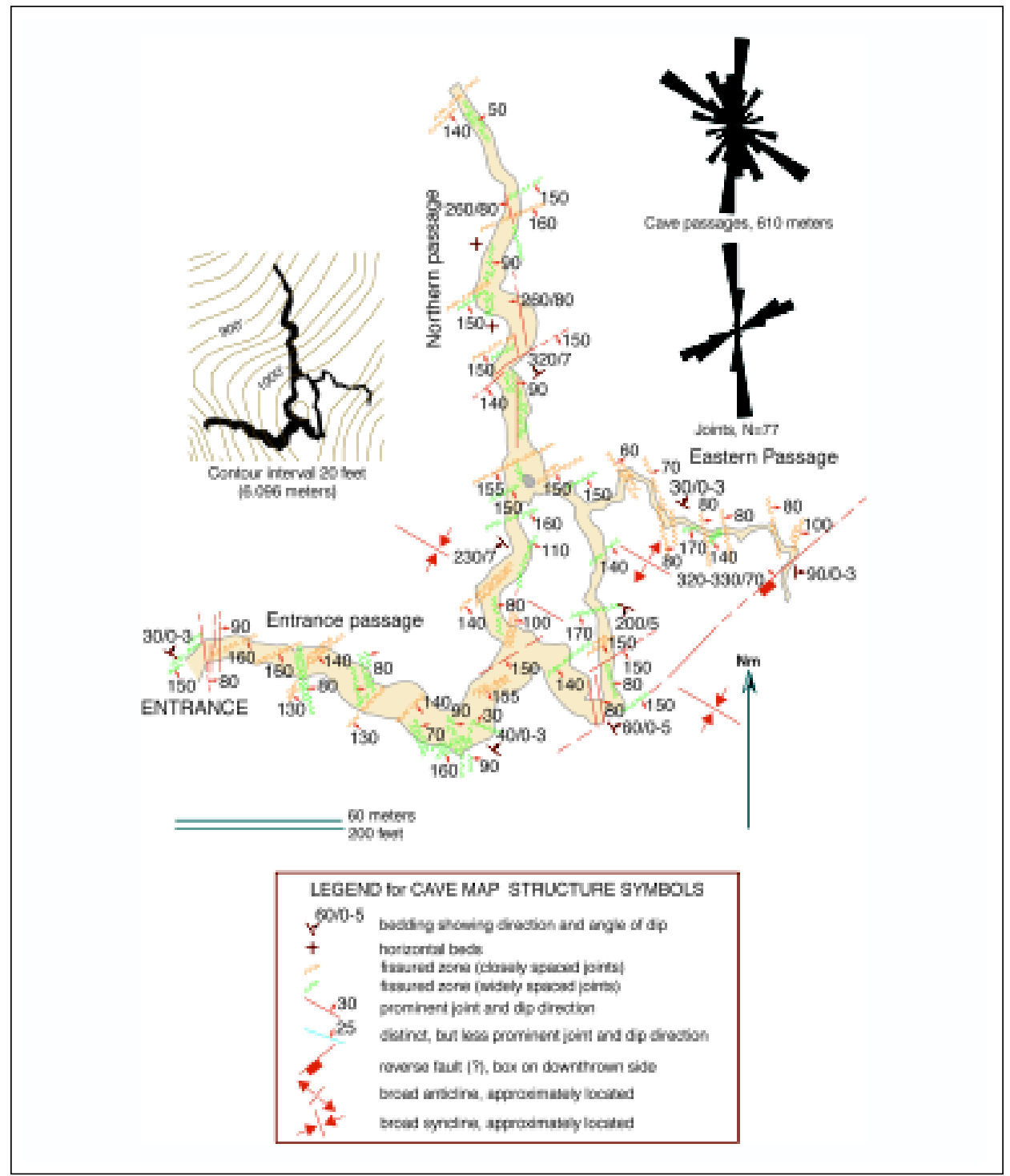

Fig. 5: Cave map with geologic features, relationship to surface topography, and rose diagrams of passage orientation and joint trends of Branson Cave.

Sl. 5: Načrt jame z geološkimi značilnostmi, odnos jamskega tlorisa in topografije površja in rozete smeri rovov in smeri razpok za Branson Cave. Legenda strukturnih simbolov na jamskih kartah (od zgoraj navzdol): -smer in vpad plasti, -horizontalne plasti, -razpoklinska cona (goste razpoke), -razpoklinska cona (široke razpoke), -glavna razpoka s smerjo vpada, -vidna, vendar manj pomembna razpoka s smerjo vpada, -reverzni prelom (oznaka je na spuščenem bloku), -blaga antiklinala, približni položaj, -blaga sinklinala, približni položaj. 


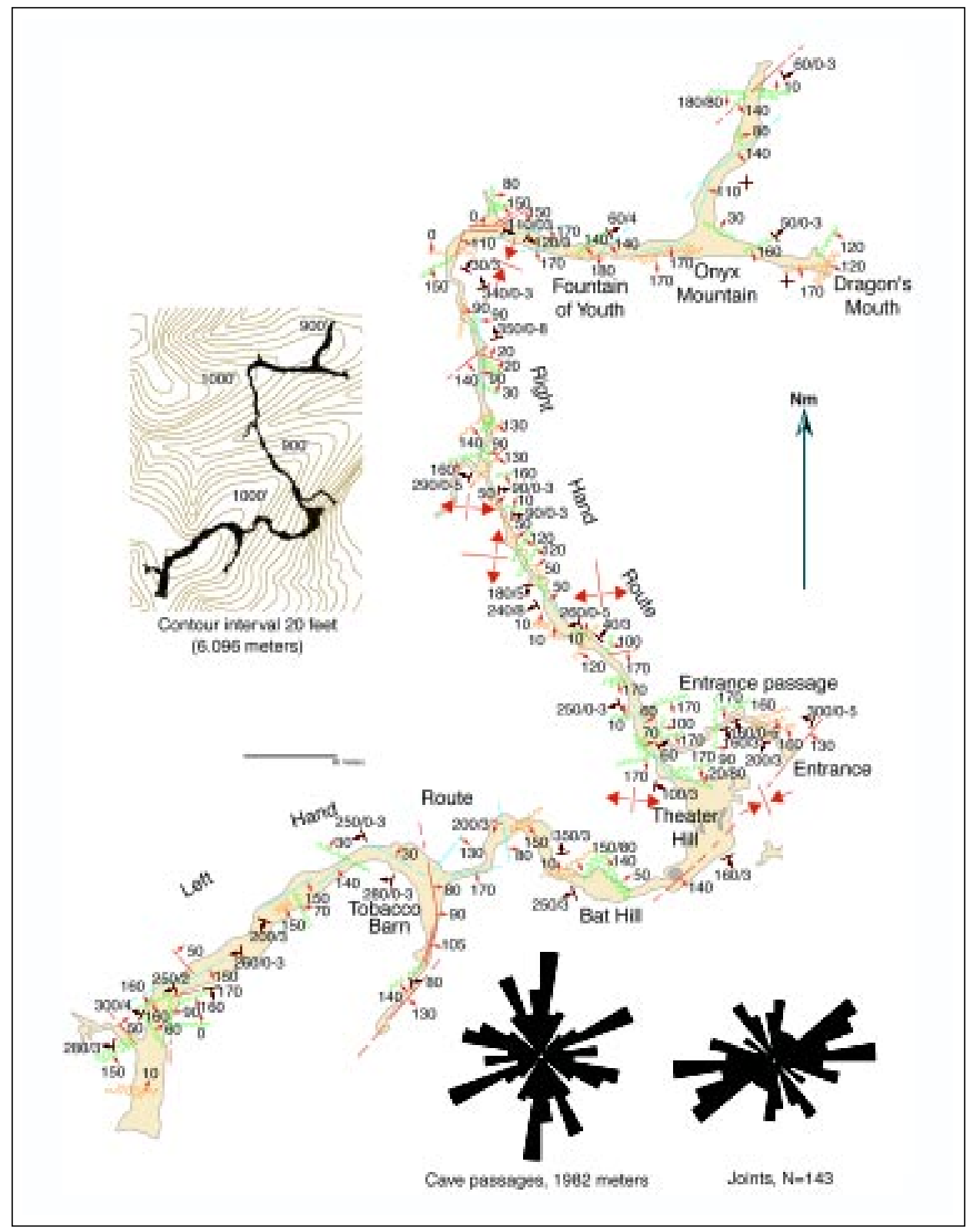

Fig. 6: Cave map with geologic features, relationship to surface topography and rose diagrams of passage orientation and joint trends of Round Spring Cavern. See figure 5 for explanation of map symbols.

Sl. 6: Načrt jame z geološkimi značilnostmi, odnos jamskega tlorisa in topografije površja in rozete smeri rovov in smeri razpok za Round Spring Cavern. Glej sliko 5 za razlago simbolov na karti. 
movement. In the southeastern part of the cave where the Branson Cave fault is projected and two passages end in breakdown, joints generally trend N-S. In the northern passage, some joints exhibit offset with dip directions of $140^{\circ}-150^{\circ}$. The principle joint directions for Branson Cave are NE (dip directions $130^{\circ}-160^{\circ}$ ) and NW (dip directions $60^{\circ}-80^{\circ}$ ).

\section{Comparison of passage directions with joint directions}

Passages of Branson Cave are developed in two principle directions, $0^{\circ}$ and $310^{\circ}$. The principle joint directions are $350^{\circ}$ (27,3 percent) and $60^{\circ}$ (19 percent). There may be some genetic relationship between the northern passage and the $350^{\circ}$ trending joints.

\section{Hydrology}

The sub-circular profile of the passages suggests initial phreatic development. However, red cave sediments, flowstone, and periodic water flow shows recent modifications to the cave in the vadose zone. During high precipitation events, water flows through the eastern passage and eventually flows south and southwest. There is no evidence of older water flow directions. Much red clay exists in the cave and occurs as deposits on the floor and in joints in the ceiling and walls indicating that the cave was filled with red clay in the past.

\section{Cave development}

Branson Cave is, for the most part, developed along a stromatolitic dolomite bed. Cave passages are related to bedding dip directions in three parts of the cave: (1) the entrance passage to the first bend, (2) the first intersection of passages on the limb of the gentle syncline, and (3) the eastern passage developed on the limb of the gentle anticline. The northern passage, which generally trends $\mathrm{N}-\mathrm{S}$, follows a visible joint. However, at one point the northern passage bends to the NE for a short distance following a joint trending in that direction indicating that joints may control the cave development in the northern passage.

Several collapse or breakdown areas have blocked several cave passages. Breakdown located in the southeastern part of the cave and at the terminus of the eastern passage is probably related to the mapped fault. Breakdown at the terminus of the northern passage occurs close to the valley slope and may be related to development of the surface topography.

\section{ROUND SPRING CAVERN}

The entrance to Round Spring Cavern is in a bluff $18 \mathrm{~m}$ above Spring Valley Creek, a tributary of the Current River (Fig. 1). It is located about $500 \mathrm{~m}$ southwest of Round Spring. The entrance is $6 \mathrm{~m}$ wide by $4 \mathrm{~m}$ high and is at $225 \mathrm{~m}$ altitude. The cave is well known for its speleothems and has had a commercial history since 1932. It is now owned by the US National Park Service. Round Spring Cavern was described by Bretz (1956).

\section{Stratigraphy}

Most of the cave (Fig. 6) is developed in the upper part of the Eminence Dolomite just below the basal sandstone of the Gasconade Dolomite. The entrance passage is within the Eminence Dolomite. Beyond the entrance passage, the cave splits into a Right-Hand and a Left-Hand Route. The Right-Hand Route is within cherty strata of the Eminence Dolomite and ends stratigraphically 
higher at the base of the Gasconade Dolomite where sandstone is exposed in the ceiling. The LeftHand Route climbs through the Eminence Dolomite to where ripple marks can be seen in the sandstone in the ceiling of the cave at the base of the Gasconade Dolomite between Theater Hill and Bat Hill. At Bat Hill, the sandstone is not visible because the ceiling lowers back into the Eminence Dolomite. West of Tobacco Barn the sandstone is again exposed in the ceiling, and the cave stopes up through the sandstone and terminates in the Gasconade Dolomite.

\section{Structure}

In the entrance passage, beds predominantly dip toward the southwest and southeast at about $3^{\circ}$. Several gentle synclines and anticlines occur in the Right-Hand Route with their axes in various orientations. Near Onyx Mountain and Dragons Mouth the bedding is subhorizontal. In the LeftHand Route, strata have a consistent dip towards the west.

In the southern part of the Right-Hand Route near the junction with the entrance passage, welldeveloped joints have a dip direction of $60^{\circ}$. Where the smaller western passage intersects the RightHand Route, the principle dip direction of joints is $130^{\circ}$. Here, the cave passage trends N-S. Where the Right-Hand Route makes an abrupt turn to the east, the frequency of vertical joints increases and trend E-W prevailes. Near the Fountain of Youth, two prominent joint sets occur; one trends about E-W with a dip direction of $170^{\circ}$, the other trends NE with a dip direction of $140^{\circ}$. The eastern terminus of the Right-Hand Route is in breakdown and flowstone where the dip direction of joints is $140^{\circ}$.

The Left-Hand Route at Theater Hill is a collapse chamber that exhibits a well-developed joint with a dip direction of $140^{\circ}$. The southern side passage at the Tobacco Barn follows the trends of joints with dip directions of $80^{\circ}, 90^{\circ}, 105^{\circ}$, and $130^{\circ}$. Just west of the Tobacco Barn in the LeftHand Route, joints are moderately well developed with dip directions of $30^{\circ}$ and cross the passage. Where the Left-Hand Route turns to the southwest, joint dip directions are $150^{\circ}-160^{\circ}$. The terminus of the Left-Hand Route is a collapse area with joint trends of E-W and N-S.

\section{Comparison of passage directions with joint directions}

Passages in Round Spring Cavern are developed along four prominent trends, $0^{\circ}-10^{\circ}, 60^{\circ}-70^{\circ}$, $330^{\circ}-340^{\circ}$, and $280^{\circ}-290^{\circ}$. Dominant joint trends are $80^{\circ}-90^{\circ}$ and $50^{\circ}-60^{\circ}$. Comparison of rose diagrams of cave passages and joints shows no good correlation, even though several areas of the cave have moderately well-developed joints parallel to the cave passage (Fig. 6).

\section{Hydrology}

The initial development of Round Spring Cavern was probably phreatic and has been modified by recent water flow in the vadose zone and stoping. Water flow in the stream in the Right-Hand Route is southeast toward Spring Valley Creek, and likewise in the Left-Hand Route, east toward Spring Valley Creek. Bedding dips are generally to the west and southwest. Both streams have cut small lower subsidiary passages that drain to Spring Valley Creek from other parts of the bluff near the entrance to the cave. The entrance passage is probably younger than the main passages and during high precipitation events water drains from Round Spring Cavern into Spring Valley Creek. Much red clay is found throughout the cave and occurs in joints in the ceiling and walls indicating the cave was probably filled with the red clay in the past. 


\section{Cave development}

Initial phreatic development of Round Spring Cavern occurred in the upper part of the Eminence Dolomite. Early water flow was probably from south-southwest to north-northeast since the LeftHand Route is higher than the Right-Hand Route. This direction is toward the Current River. Changes in surface and ground-water flow have caused drainage in the vadose zone to flow eastward to Spring Valley Creek. Later modifications to the cave include stoping up to and through the basal sandstone of the Gasconade Dolomite.

\section{WIND CAVE}

The entrance of Wind Cave is at $230 \mathrm{~m}$ altitude on a steep-sided slope along the Current River (Fig. 1). The large entrance is $15 \mathrm{~m}$ wide by $12 \mathrm{~m}$ high.

\section{Stratigraphy}

Wind Cave (Fig. 7) is developed in the upper part of the Eminence Dolomite just below the basal sandstone of the Gasconade Dolomite. Much of the main passage and the southwest passage follow a stromatolitic dolomite layer. In the Tip-Top Mountain Room of the southwest passage, the cave stopes up to the basal sandstone of the Gasconade Dolomite leaving much breakdown in the chamber. Nearly the entire southeast passage follows the stromatolitic dolomite.

\section{Structure}

In the northern part of the cave, beds dip northerly from $0^{\circ}$ to $5^{\circ}$. A gentle anticline exists in the Tip-Top Mountain Room and possibly is the same structure as the anticline observed north of the Coral Crawl where the southwest and southeast passages intersect.

A possible fault breccia was observed along well-developed joints with dip direction $200^{\circ}$, dipping $85^{\circ} \mathrm{SE}$ at Blowhole in the main passage. This same trend was noted at Confusion Junction where the zone of fracturing is about $60 \mathrm{~m}$ wide. Much of the southwest passage is developed along a NE trending joint set that is visible between the Coral Crawl and Tip-Top Mountain Room. Other, less-developed joints in the Tip-Top Mountain Room have dip directions of $100^{\circ}, 80^{\circ}$, and $20^{\circ}$. The southwest passage terminates in breakdown at the Bitter End. In the southeast passage along N-S trending Amble Alley, a dominant easterly trending joint set cuts a moderately well-developed N-S joint set.

\section{Comparison of passages with joint directions}

Most cave passages are developed in three prominent trends, $350^{\circ}-10^{\circ}(28,5$ percent $), 40^{\circ}-50^{\circ}$ (13 percent), and $310^{\circ}-320^{\circ}$ (11 percent). The most prominent joints trend $280^{\circ}-300^{\circ}(26,4$ percent), $350^{\circ}-0^{\circ}(12,5$ percent $)$, and $50^{\circ}-60^{\circ}(11$ percent $)$. The only correlation between cave passage trends and joint directions is in the N-S direction (Fig. 7).

\section{Hydrology}

A stream that issues from the entrance of Wind Cave has developed a lower level to much of the cave. The upper level shows phreatic development while the lower level exhibits vadose modifications. Like most caves in the Ozarks, red clay occurs in the passages that has been eroded and removed by the stream. Clay deposited in joints in the walls and ceiling indicate that the cave was filled with the red clay in the past. 


\section{Cave development}

For the most part, Wind Cave developed along a stromatolitic dolomite horizon in the Eminence Dolomite under phreatic conditions. Once conditions changed to vadose development, streams cut the lower levels and stoping in many parts of the cave caused the large amount of breakdown that exists. Stoping in the Tip-Top Mountain Room has exposed the base of the overlying Gasconade Dolomite. Part of the southwest passage from Coral Crawl to the Tip-Top Room is developed along a prominent NE trending joint, whereas most of the remainder of the cave does not show development along joint trends.

\section{COOKSTOVE CAVE}

The entrance to Cookstove Cave is in a sinkhole on a hillside at $277 \mathrm{~m}$ altitude about $5,5 \mathrm{~km}$ north of the Current River (Fig. 1). The entrance is $7,5 \mathrm{~m}$ wide by $3 \mathrm{~m}$ high and the passage steeply drops $10 \mathrm{~m}$ to the main part of the cave. The passages are quite large with ceiling heights as much as $10 \mathrm{~m}$ and widths as much as $30 \mathrm{~m}$. Cookstove Cave was described by Taylor (1977).

\section{Stratigraphy}

The cave (Fig. 8) is developed in dolomite of the middle part of the Gasconade Dolomite. Cherty dolomite is exposed at the entrance. As the cave drops down to its lowest part at the Main Gallery, sandstone of the lower part of the Gasconade is exposed. Most of the northern part of the cave is developed in a stromatolitic dolomite.

\section{Structure}

Two anticlines with axial trends NE and a syncline with an axial trend to the NNW occur in Cookstove Cave. In the entrance passage and Sentinel Hall north-trending joints terminate against east-trending joints. However, in the Main Gallery, the opposite relationship exists.

\section{Comparison of passages with joint directions}

The geologic map of Cookstove Cave and rose diagrams (Fig. 8) show good correlation between joints and cave passage trends. The dominant trends of passages are $350^{\circ}-10^{\circ}$ (24 percent), $290^{\circ}-300^{\circ}$ (14 percent), and $80^{\circ}-90^{\circ}\left(13\right.$ percent). The $350^{\circ}-0^{\circ}$ and $80^{\circ}-90^{\circ}$ trends correlate well with the dominant joint trends $350^{\circ}-0^{\circ}$ (30 percent) and $80^{\circ}-90^{\circ}$ (26 percent).

\section{Hydrology}

The active streams in Cookstove Cave have developed smaller and lower passages than the main part of the cave and generally flow to the south and southwest. Much red clay is seen on the floor of the cave and is overlain by sand and breakdown blocks, the sand being washed in since much of the clay has been removed.

\section{Cave development}

Cookstove Cave may have developed as a large spring system for a tributary of the Current River to the northwest of the cave. At some point the cave was filled with red clay that was later mostly removed. Breakdown from stoping of the large chambers overlies much of the clay and this collapse has enlarged the cave. 
S. Šebela \& R.C. Orndorff \& D.J. Weary: Geological controls in the development of caves in the south-central Ozarks of...

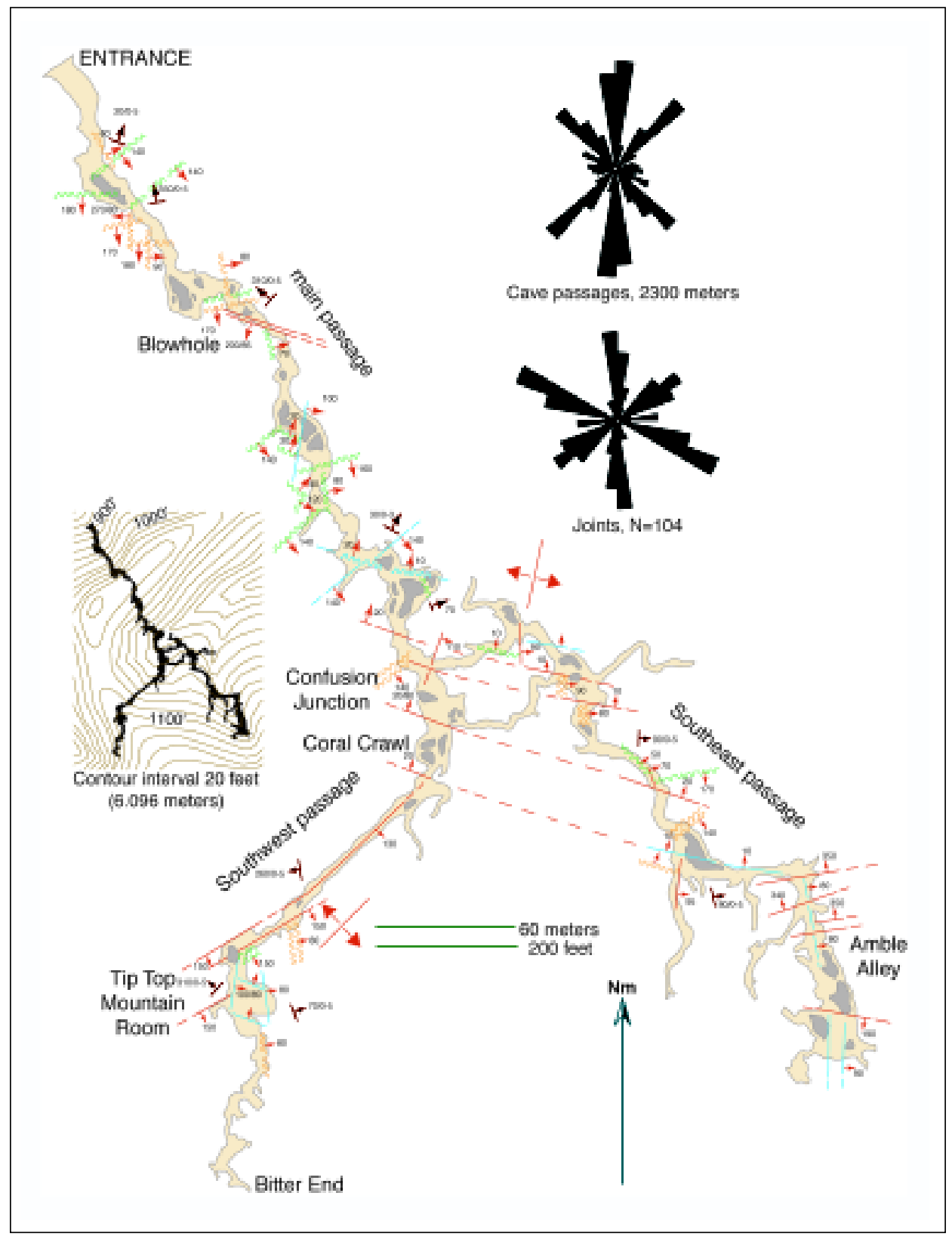

Fig. 7: Cave map with geologic features, relationship to surface topography and rose diagrams of passage orientation and joint trends of Wind Cave. See figure 5 for explanation of map symbols. Sl. 7: Načrt jame z geološkimi značilnostmi, odnos jamskega tlorisa in topografije površja in rozete smeri rovov in smeri razpok za Wind Cave. Glej sliko 5 za razlago simbolov na karti. 

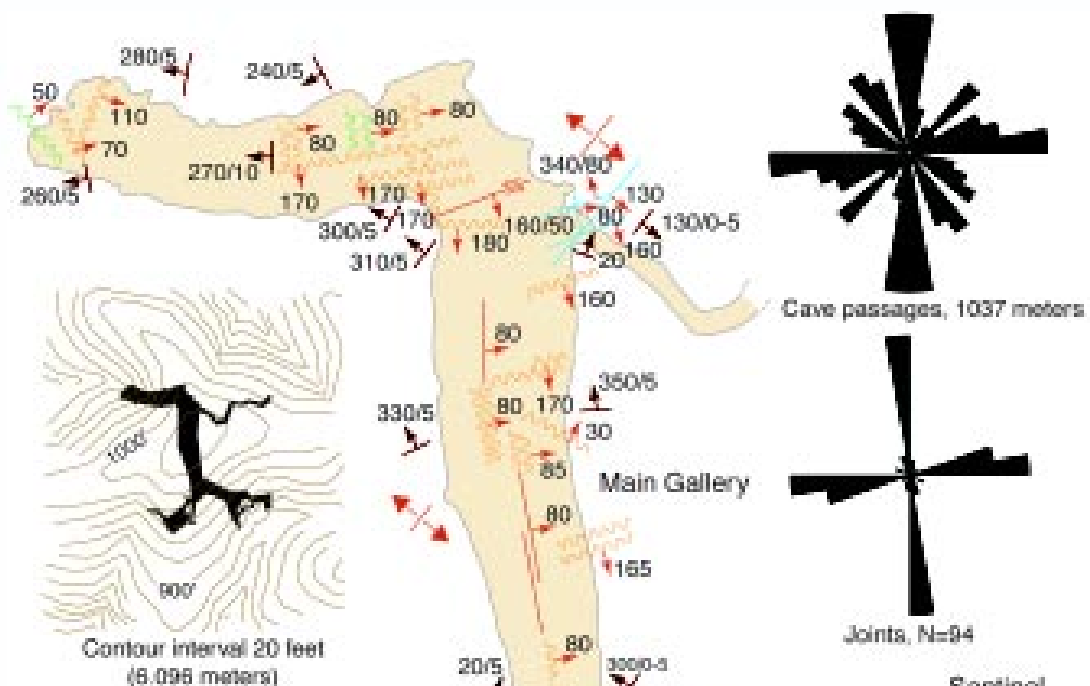

(6.096 menerg)
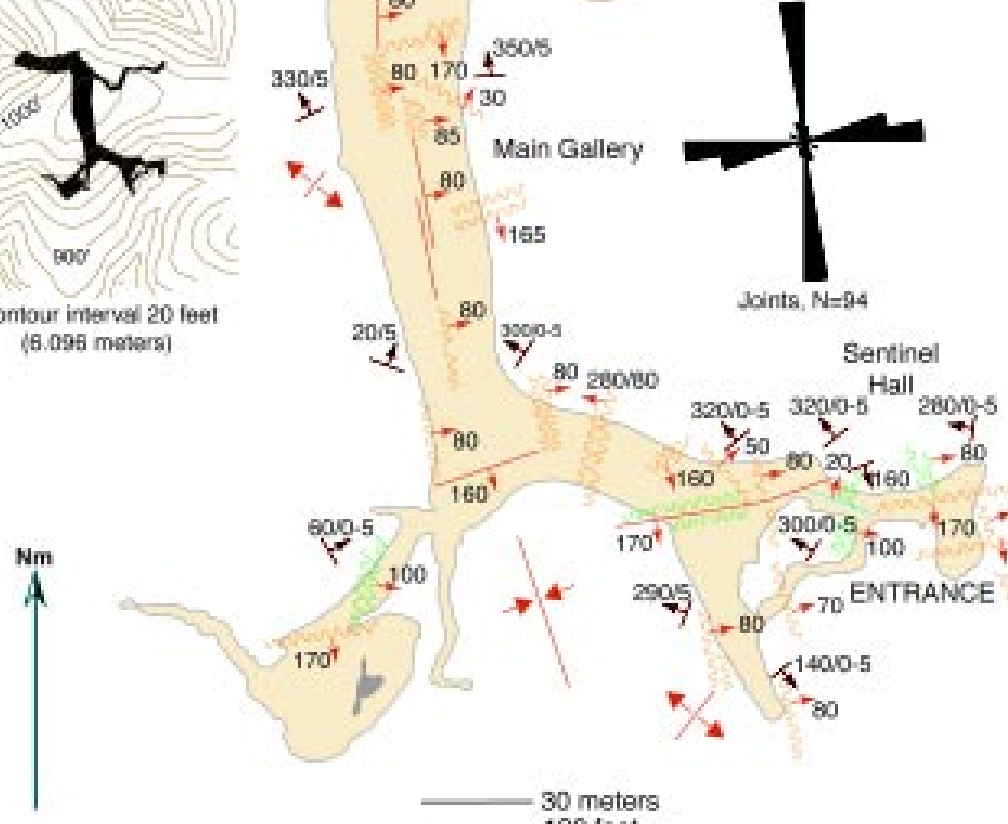

120 leet

Fig. 8: Cave map with geologic features, relationship to surface topography and rose diagrams of passage orientation and joint trends of Cookstove Cave. See figure 5 for explanation of map symbols. Sl. 8: Načrt jame z geološkimi značilnostmi, odnos jamskega tlorisa in topografije površja in rozete smeri rovov in smeri razpok za Cookstove Cave. Glej sliko 5 za razlago simbolov na karti. 


\section{RED CLAY DEPOSITS}

A common characteristic of Ozark caves is the deposits of silty and sandy red clay on the floors, ceilings, and walls. The red clay fills the irregularities in the walls and ceilings and is locally several meters thick on the floors. In places gravel layers are interbedded in the clay. X-ray diffraction analyses of the clay indicates that clay minerals are kaolinite, illite, and montmorillonite and nonclay minerals are dolomite, K-feldspar, plagioclase, and quartz (Reams 1968). This suggests that the sediments were derived from residuum at the surface. Laboratory and field observations by Reams (1968) indicated that the caves did not have to be completely filled with mud to account for the clay deposits in the ceiling; muddy water flowing through a cave system could deposit clay in the bedrock irregularities.

Radiocarbon analysis of clay indicated ages of $4215+/-175$ years and $6220+/-200$ years (Reams 1968). The oldest known fossils from the clay deposits are Wisconsinan (late Pleistocene) age (Reams 1968).

\section{CONCLUSIONS}

The prevailing geologic control on cave development is apparently bedding plane dip and preferred strata. Cave passages in Ozark caves commonly are curvilinear, which suggests that bedding planes play an important role in cave development (Palmer 1991). Most of the caves mapped for this study are developed along a stromatolitic dolomite horizon and most occur just beneath sandstone beds. Some subtle correlations between cave passages and joint trends indicate that the caves probably initially developed along the intersection of vertical joints and more permeable beds during phreatic conditions, but as the cave systems enlarged, bedding became the dominant factor in development. The caves probably formed under shallow phreatic conditions and silty and sandy red clays derived from surface residuum were subsequently deposited. Once in the vadose zone, the caves were modified by cave streams, which removed much of the red clay. Upward stoping, which created collapse, is the origin of the breakdown. The age of the caves is problematic. Oldest known fossils from the red clay are of Wisconsinan (late Pleistocene) age and radiocarbon dates of 4215+/-175 and $6220+/-200$ years have been reported (Reams 1968). These dates only show the timing the last cave fill as Pleistocene and Holocene. The caves may have developed in the Tertiary or can even be older and may have had several periods of cave fill and erosion.

\section{ACKNOWLEDGMENTS}

The research for this article was done between 1996 and 1999. Stanka Šebela would like to thank the U.S. Geological Survey, especially Richard W. Harrison and Randall C. Orndorff for their invitation to work on the project. Travel and living expenses for Stanka Šebela were provided by Slovene Sciences Foundation (1996), Fulbright grant (1998), and the U.S. Geological Survey (1999). Field work was done with the help of many people. The authors would like to thank the Ozark National Scenic Riverways (Victoria Grant and Charles Putnam), the U.S. Geological Survey (Richard W. Harrison, Robert C. McDowell, and Robert E. Weems), and the Cave Research Foundation (Mick Sutton, Sue Hagan, Robert R. Osburn, and Scott House). 


\section{REFERENCES}

Aley, T., 1975: A Predictive Model for Evaluating the Effects of Land Use and Management on the Quantity and Quality of Water from Ozarks Springs.- Final report, USFS Speleology 18, 1185.

Aley, T.J., and Aley, C., 1987: Groundwater study - Ozark National Scenic Riverways.- Protem, Mo., Ozark Underground Laboratory, National Park Service Contract CX 6000-4-0083, $222 \mathrm{p}$.

Bretz, J.H. 1956: Caves of Missouri.- State of Missouri Department of Buisness and Administration, Division of Geological Survey and Water Resources, v. 39, $2^{\text {nd }}$ ser., pp.490, Rolla, Missouri.

Brod, L. G. 1990: The Effect of Faulting on Missouri Caves.- Missouri Speleology, Vol. 30, Numbers 1-2, Journal of the Missouri Speleological Survey, 1-50 pp.

Imes, J. L., 1990: Major geohydrologic units in and adjacent to the Ozark Plateaus Province, Missouri, Arkansas, Kansas, and Oklahoma-Ozark aquifer.- U.S. Geological Survey Hydrologic Atlas HA-711-E, 3 sheets, scale 1:750,000.

Imes, J.L. and Kleeschulte, M.J., 1995: Seasonal ground-water level changes (1990-93) and flow patterns in the Fristoe unit of the Mark Twain National Forest, southern Missouri: U.S. Geological Survey Water-Resources Investigations Report 95-4096, 1 sheet.

Orndorff, R.C., Šebela, S., Weary, D.J., McDowell, R.C., Harrison R.W. \& Weems, R.E., 1999: A Geologic framework in karst: U.S. Geological Survey contributions to the Hydrogeology of the Ozarks of Missouri.-Hydrogeology and Engineering Geology of Sinkholes and Karst1999, Proceedings of the Seventh Multidisciplinary Conference on Sinkholes and the Engineering and Environmental Impacts of Karst, Harrisburg-Hershey/Pennsylvania/1014 April 1999, 57-62, A.A.BALKEMA, Rotterdam/Brookfield

Palmer, A. N., 1991: Origin and morphology of limestone caves.-Geol. Soc. of America Bull. V. 103, 1-21, s.l.

Reams, M. W., 1968: Cave sediments and the geomorphic history of the Ozarks.- Washington University, Department of earth Sciences, A dissertation presented to the Graduate School of arts and Sciences of Washington University in partial fulfillment of the requirements for the degree of doctor of philosophy, Saint Louis, Missouri, $167 \mathrm{pp}$.

Taylor, R. L., 1977: Cookstove cave.- Missouri Speleology, Vol 17, Numbers 1-2, 32-35 pp., Journal of the Missouri Speleological Survey.

Unklesbay, A.G., and Vineyard, J.D., 1992: Missouri geology - Three billion years of volcanoes, seas, sediments, and erosion: Columbia, Mo., University of Missouri Press, 189 p.

Vineyard, J.D. \& Feder, G.L., 1982: Springs of Missouri.- Missouri Geological Survey and Water Resources, Water Resources Report 29, 212 pp., Rolla, Missouri. 


\section{GEOLOŠKE ZAKONITOSTI PRI RAZVOJU JAM V OSREDNJEM DELU} JUŽNIH OZARKOV, MISSOURI, ZDA

\section{Povzetek}

U.S. Geological Survey opravlja geološko kartiranje (1:24.000 in 1:100.000) kraških terenov v osrednjem delu južnih Ozarkov, v Missouriju. Na kartiranem področju najdemo številne kraške jame, kraške izvire, vrtače. Teren je zgrajen iz predkambrijskih riolitov in granita ter Kambrijskih in Ordovicijskih dolomitov in peščenjakov. Nadmorske višine so od 120-400 m, teren je hribovit in premrežen s številnimi površinskimi rekami in ponikalnicami.

Največji kraški izviri v ZDA se nahajajo v Ozarkih. Big Spring ima povprečen pretok $12 \mathrm{~m}^{3} / \mathrm{sec}$ in Greer Spring $8 \mathrm{~m}^{3} / \mathrm{sec}$.

Terenske raziskave smo opravljali s presledki v obdobju od oktobra 1996 do vključno maja 1999. V tem času smo obiskali 23 kraških jam, izmed katerih smo jih 18 podrobno geološko kartirali. Za ta članek smo izbrali 4 jame, in sicer: Branson cave, Round Spring cavern, Wind cave in Cookstove cave, in sicer zaradi zanimivih strukturno-geoloških podatkov.

Prevladujoča geološka struktura po kateri so razvite jame so lezike in prioritetna plast. Statistično obdelani podatki glavnih smeri rovov in glavnih smeri razpok se dobro pokrivajo le v smeri S-J. Večina jam, ki smo jih geološko kartirali za ta članek je razvita znotraj stromatolitno-dolomitnega horizonta, večinoma tik pod plastjo peščenjaka. Jamski rovi so se verjetno inicialno razvili vzdolž sečišč med razpokami in bolj prepustnimi plastmi in sicer v freatičnih pogojih. Kasneje so bile jame zapolnjene $\mathrm{v}$ plitvih freatičnih pogojih $\mathrm{z}$ rdečo glino, ki je ostanek površinskega residiuma. Z vadoznimi pogoji je bil del rdeče gline odstranjen iz rovov, rovi so se poglabljali s podzemeljskimi potoki, razvijali so se podori. Glede na določitev starosti jamskih sedimentov v jamah v Ozarkih, lahko zanesljivo določimo le obdobje odlaganja sedimentov to je Pleistocen in Holocen. Inicialno so se jamski rovi razvili mnogo prej, kdaj pa ni mogoče zanesljivo določiti. 